\title{
Surgical Treatment of Primary Trigeminal Neuralgia: Comparison of the Effectiveness Between MVD and MVD+PSR in a Series of 210 Patients
}

\author{
Primer Trigeminal Nevraljinin Cerrabi Tadavisi: Mikrovasküler \\ Dekompresyon+Parsiyel Duyusal Rizotomi ile Mikrovasküler \\ Dekompresyonun Etkinliğinin 210 Hastalık Bir Seride Karşılaştırılması
}

\author{
Liangwen ZHANG, Yuan ZHANG, Chao LI, Shugan ZHU \\ Qilu Hospital, Shandong University, Department of Neurosurgery, Jinan, China
}

Correspondence address: Shu-gan ZHU / E-mail: drzhusg@tom.com

\begin{abstract}
AIM: To evaluate the effectiveness of microvascular-decompression (MVD) or MVD+partial-sensory-rhizotomy (PSR) on the treatment of primary trigeminal neuralgia (TN).

MATERIAL and METHODS: 210 TN patients were retrospectively studied, among which there're 142 cases underwent MVD and 68 cases underwent MVD+PSR.

RESULTS: In MVD group, pain vanished in 128, obviously relieved in 9, and 137 cases were profited from MVD. In 82 cases with a follow-up over 2 years, pain vanished in 74, pain sometime occurred in 5 which could be relieved by oral medicine, 3 cases could not be controlled effectively by medicine. In MVD+PSR group, pain completely vanished in 67 cases, not changed in 1 case. In 47 cases with a follow-up over 2 years, pain sometime occurred in 2 which could be relieved by carbamazepine, the others were completely pain-free. The short-term pain-free rate of MVD+PSR group was obviously higher than MVD group $(P<0.05)$, after a follow-up over 2 years, the former was still higher than the later, $95.7 \%$ and $90.2 \%$ respectively, without significant difference in statistics.

CONCLUSION: MVD+PSR was obviously superior to MVD in completely eliminating pain in short-term period after operation, however, longer pain-free rate need even longer time to follow up. Identifying the responsible vascular exactly and handling it reasonably were key to both groups.
\end{abstract}

KEYWORDS: Trigeminal neuralgia, Microvascular decompression, Sensory rhizotomy

öz

AMAÇ: Primer trigeminal nevralji tedavisinde mikrovasküler dekompresyon ile mikrovasküler dekompresyon+parsiyel duyusal rizotomi ile etkinliğinin değerlendirilmesi.

YÖNTEM ve GEREÇ: Trigeminal nevraljisi olan 210 hasta retrospektif olarak incelendi, bu hastalardan 142'sine mikrovasküler dekompresyon uygulanırken, 68'ine mikrovasküler dekompresyonun yanı sıra parsiyel duyusal rizotomi uygulanmıştır.

BULGULAR: Mikrovasküler dekompresyonun uygulandığı 137 hastadan 128'inde ağrı giderilmiş, 9'unda ise ağrıda bariz bir azalma olmuştur. Olguların 82'sinin 2 yıllık takibinde; 74 olguda ağrı görülmedi, 5 olguda nadir ağrı oldu ve oral ilaçlar ile kontrol edilebildi, 3 olgunun ağrısı ise oral ilaçlar ile kontrol edilemedi. Mikrovasküler dekompresyonun yanı sıra parsiyel duyusal rizotomi yapılan hastalardan 67'sinde ağrı görülmedi, 1'inde ağrı değişmedi. Bu olguların 47'sinin 2 yıllık izleminde; 2 olguda ağrı oldu ve karbamazepin ile rahatladı, diğer olgularda ağrı görülmedi. Erken dönemde mikrovasküler dekompresyon+parsiyel duyusal rizotomi yapılan olgularda, sadece mikrovasküler dekompresyon yapılan olgulara göre ağrısız bir dönem elde edilmiştir $(\mathrm{P}<0.05)$. İki yıllık sonuçlar incelendiğinde mikrovasküler dekompresyon+parsiyel duyusal rizotomi olgularının \% 95,7 sinde ağrı yok iken sadece mikrovasküler dekompresyon yapılan olguların \% 90,2'sinde ağıı yoktu; ancak iki grup arasında anlamlı istatistiksel fark bulunmadı.

SONUÇ: Mikrovasküler dekompresyon+parsiyel duyusal rizotomi ile mikrovasküler dekompresyon karşılaştıııldığında: erken dönemde mikrovasküler dekompresyon+parsiyel duyusal rizotomi mikrovasküler dekompresyona daha üstündür; ancak uzun dönemli karşılaştırma yapmak için takip sürelerinin uzatılarak değerlendirme yapılması gereklidir. Her iki grup içinde sorumlu vasküler etiyolojinin çok iyi ortaya konarak incelenmesi gereklidir.

ANAHTAR SÖZCÜKLER: Trigeminal nevralji, Mikrovasküler dekompresyon, Sensorial rizotomi 


\section{INTRODUCTION}

Trigeminal neuralgia (TN) is a severe, intermittent, electric shock-like pain in face, which is not life-threatening in itself, but the devastating pain and other symptoms such as anxiety and depression seriously deteriorate the quality of life. To date, various surgical procedures for treatment of TN have been applied, such as percutaneous balloon microcompression $(\mathrm{PBC})(14,22)$, radiofrequency thermorhizotomy (RTR) $(10,16)$, partial sensory rhizotomy (PSR) $(11,27)$, and microvascular decompression (MVD) $(7,21$, 25). Unfortunately, there is no ideal surgical procedure could immediately and completely relieve this intolerable pain, eliminate all needs for medications, let alone no recurrence of TN. PSR has now rarely been performed for TN because of its higher recurrence and intolerable dysesthesia due to nerve damage. In recently reported 2 studies on PSR, one gain completely pain relief immediately after operation but had recurrence more than $50 \%$ with a 5 years follow up (11); the other was in $49 \%$ recurrence for PSR, which was obviously higher than 6\% in MVD group at the same period (27). As the only technique which corrects the hypothesized vascular etiology by repositioning the responsible vessel, MVD provides the highest rate of long-term patient's satisfaction with the lowest rate of pain recurrence, which is also the sole procedure can cure pain without destroying trigeminal nerve, but there is still a high unsuccessful and recurrent rate of MVD, Tatli (23) reviewed 4884 patients underwent MVD reported in literature, found the reported initial pain relief, follow-up pain free and recurrence rates of the MVD group range from $76.4-98.2 \%, 62-89 \%$ and 4-38\%, respectively.

In practical occupation of every specialist, he will wonder if MVD+PSR could attain a better outcome than solely MVD or PSR. Maybe some specialists have performed MVD+PSR in their practice, no matter how it turns out, there is no report on it. From January 2005 to September 2010, 210 consecutive patients undergoing posterior fossa craniotomies for TN in our hospital, of which, 142 cases underwent MVD and the other 68 cases underwent MVD+PSR.By comparing the outcomes of MVD and MVD +PSR, we would like to suggest a more effective procedure may benefit to more TN patients in future.

\section{MATERIAL and METHODS}

\section{Patient Selection}

We retrospectively analyzed 210 patients [87 male (41.4\%) and 123 female (58.6\%)] with primary TN (either typical or atypical). The median age was 57.7 years (range: $26-76$ years). The length of clinical history averaged from 3 months to 31 years. All patients selected were treated with carbamazepine before operation and found at least one artery compression in operation. The CT or MRI was performed to all patients to eliminate symptom TN or tumor. There were 4 cases of TN combined with multiple sclerosis (MS).

\section{Methods selection}

All patients were informed of the merits and shortcomings of the two methods before operation. In general, the MVD+PSR was suggested in the following conditions: older than 65; responsible artery being not clear-cut or not be handled well enough in operation; companied multiple sclerosis; significant adhesion of arachnoid to roots. To younger patients, especially younger than 50-years old, or those would not want to tolerate numbness or paresthesia after operation, MVD was suggested.

In our series, 142 cases (median age: 56.4 years) were treated with MVD alone (without any additional cutting or coagulation of the sensory root) and 68 cases (median age: 60.2 years) were treated with MVD+PSR (1/4-1/5 breadth of the sensory root was cut off).

\section{Surgical techniques}

Under general anaesthesia, patients were in lateral decubitus position with head dropping downward in $15^{\circ}$ and turn to opposite side in $10^{\circ}$. In all cases, surgery was performed by the same neurosurgeon. With skilled manipulation and attentiveness, we made personal modifications may different from classical microsurgical techniques in some aspects: The skin incision was near the edge of the hair behind the ear and the bone window was just $1.5 \mathrm{~cm}-2 \mathrm{~cm}$ in diameter; the angle of the lateral sinus to sigmoid sinus was exposed and cerebrospinal fluid was patiently drained to minimize cerebellar retraction, sufficiently expose the space between the tentorium of cerebellum and VII-VIII complex; free the compressive artery from the REZ (root entry zones) by Teflon cotton, without compression to the nerve directly; explore the whole nerve and free the entire root from any arachnoid adhesion. With each patient's prior consent, PSR was performed after handing of the responsible artery, about 1/4-1/5 breadth of sensory root was cut off by scissors without any coagulation, the section was performed as close as possible to the brain stem (Figure 1); Arterial loops were repositioned and further protected with oblong pads of teased Teflon cotton, and then the artery was suspended to the tentorium by glue in three cases; Care must be taken not to overlook vein compression, the veins were coagulated and cut off, such as the pontine veins adhere to REZ. Try your best to seal the dura closely to avoid probable cerebral spinal fluid leakage, but the most important thing was carefully sealing the mastoid air cell with bone wax.

\section{Statistical analysis}

All the data was analysed using SPSS 13.0 for Windows Release (SPSS Inc., Chicago, IL). A Fisher exact test was used in comparisons of variables data for statistical evaluation. In all comparisons, $\mathrm{P}<0.05$ was considered significant.

\section{RESULTS}

\section{Characteristic of the Series}

Patient age at surgery ranged from 26 to 76 years (average 57.7 years), 33 patients were younger than 50 years old, 145 
patients were between 50 and 65 years of age, 32 patients were more than 65 years old, and there was a higher mean age of MVD+PSR group than MVD group. 123 were females and 87 were males, there was a higher ratio of female to male in both groups. Furthermore, there was a higher rate of right lateralization of pain in MVD+PSR group than MVD group (Fisher $\mathrm{P}=0.0478<0.05$ ), without statistical significance of

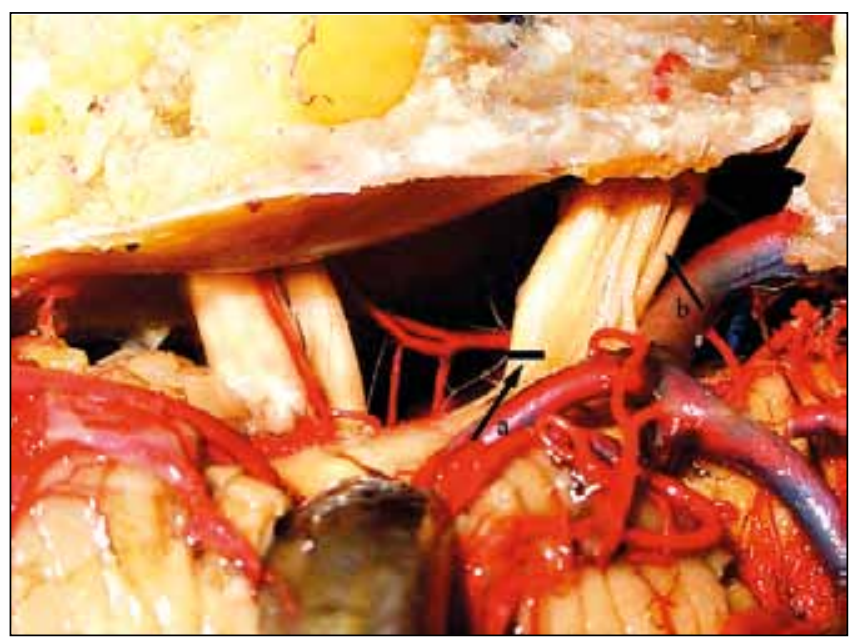

Figure 1: Anatomical image. The figure showed that after handing of the responsible artery, PSR was performed to cut off part of sensory root by scissors without any coagulation. a: the cutting length with $1 / 4-1 / 5$ breadth of trigeminal nerve sensory root; b: trigeminal nerve motor root (Black Arrow). left and bilateral pain in two groups. The number of divisions involved was as follows: only one division in 88 patients, two in 107 patients, and all three divisions in 15 patients. All patients had taken carbamazepine before operation, and there were 40 underwent Alcohol or glycerin injection, 55 underwent radiofrequency therapy before operation. To see Table I: clinical Characteristics of MVD\&MVD+PSR.

\section{Surgical findings}

As the responsible artery (or neurovascular conflict, NVC), superior cerebellar artery (SCA) was in dominant both in MVD and MVD+PSR group, about $76.1 \%$ ( 108 cases) and 86.8 $\%$ (59 cases) in proportion (Figure $2 A$ ), and there were another 23 and 4 cases accompanied with arteriae inferior anterior cerebelli (IACA) compression in MVD and MVD+PSR group respectively. Other arteries occupied in a small proportion in both groups. Free the compressive artery from the REZ by Teflon cotton, without compression to the nerve directly (Figure 2B). Vein compressions were found in 46 cases, about $24.6 \%$ ( 35 cases) and 16.2\%( 11 cases) in MVD and MVD+PSR group respectively. Arachnoid adhesion was found in 19 cases, 12 and 7 in MVD and MVD+PSR group, respectively. In the three cases of TN companied with facial spasm in MVD group, one was found abnormal enlargement of vertebral artery, which occupied almost the whole volume of CPA, any section of the trigeminal nerve could not be exposed in vision, by gently displacing the artery by Teflon from the pone, both the pain and facial spasm disappeared after operation. In the other two cases, inferior anterior cerebelli was responsible for

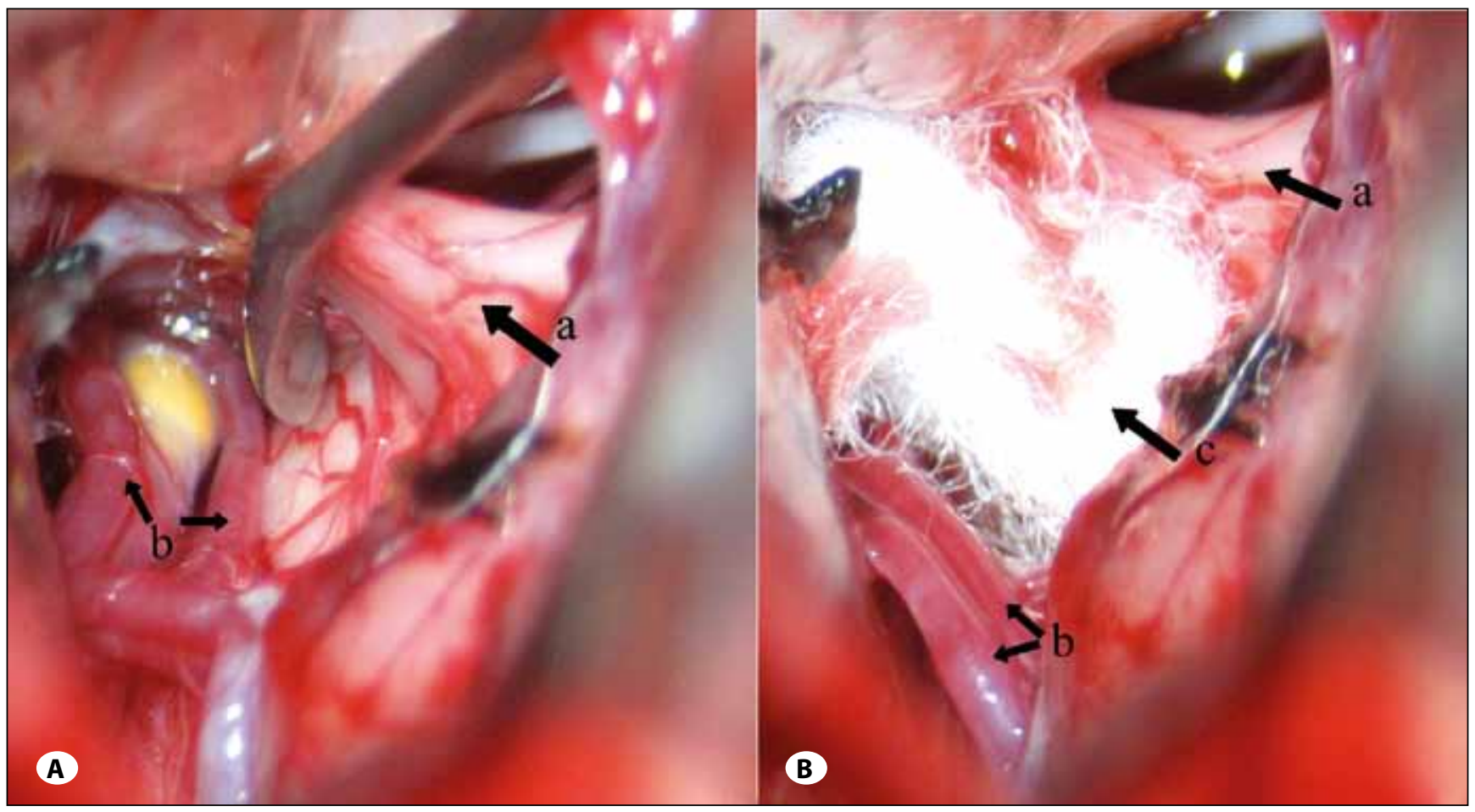

Figure 2: Intraoperative image A) Superior cerebellar artery was in dominant as the responsible artery; B) Free the compressive artery from the REZ (root entry zones) by Teflon cotton, without compression to the nerve directly. a: trigeminal nerve; b: superior cerebellar artery; c: packing material called Teflon cotton (Black Arrow). 
both diseases, SCA as the responsible artery for TN could not be ruled out in one case. To see Table II: responsible artery and abnormal findings in operation.

\section{Surgical outcomes}

Immediate outcomes after operation: pain vanished in 128 patients $(90.1 \%)$, obviously relieved in 9 patients, no change in 5 patients in MVD group; pain completely vanished in 67 patients (98.5\%), not changed in 1 patients in MVD+PSR group, there was an obviously higher percentage of pain- free of MVD+PSR group (\%) than MVD group (\%). This finding was statistically significant (Fisher $\mathrm{P}=0.0409<0.05$ ).

Follow up outcomes: delayed cure occurred in 2 cases in MVD group, and the pain vanished in 6 days and 13 days after operation respectively. In the 82 cases with a follow-up more than 2 years in MVD group, pain vanished in 74, pain sometimes occurred in 5 which could be relieved by oral medicine (carbamazepine), the last 3 cases could not be controlled effectively by medicine. In the 47 cases with a follow-up more than 2 years in MVD+PSR group, pain sometimes occurred in 2 which could be relieved by carbamazepine, the others were completely pain-free. Although there was a higher ratio of completely pain-free in MVD+PSR group than MVD group after operation for more than 2 years, this finding did not reach statistical significance (Fisher $P=0.3251>0.05$ ). To see Table III: Follow up outcomes of MVD\&MVD+PSR.

\section{Complications}

There is no mortality in our group, no leakage of cerebrospinal fluid, no hearing loss or ataxia occurred. Transient vertigo occurred in 31 patients and most vanished during the duration of hospital stay. Labial herpes occurred in 49 patients (23.3\%), 35 in MVD and 14 in MVD+ PSR group, respectively. postoperative cognitive dysfunction(POCD) occurred in 5 cases, presented as absurd and restlessness, impaired orientation force and perceptivity, especially serious at night, symptoms occurred in the first 3 days postoperative then vanished by taking droperidol. Mild facial hypoesthesia or numbness was present in 23 cases of MVD+PSR group and 2 cases of MVD group, which located around the corner of the mouth. Body temperature higher than 38.5 degree Celsius happened in 4 patients, and there was no bacterium growth in bacterial culture of cerebrospinal fluid. Intracranial pneumatocele occurred in 2 patients and vanished before discharge.

Table I: Clinical Characteristics of MVD\&MVD+PSR

\begin{tabular}{|c|c|c|c|}
\hline & MVD & MVD+PSR & Total /means \\
\hline Number of patients (M/F) & $142(59 / 83)$ & $68(28 / 40)$ & 210 \\
\hline Age range (years) & $26-71(56.4)$ & $55-76(62.5)$ & $26-76(57.7)$ \\
\hline Duration of symptoms (years) & $3 \mathrm{~ms}-31 \mathrm{ys}$ & $6 m s-35 y s$ & $3 \mathrm{~ms}-35 \mathrm{ys}$ \\
\hline \multicolumn{4}{|l|}{ Lateralization of pain } \\
\hline right & 89 & 32 & 121 \\
\hline left & 52 & 36 & 88 \\
\hline Bilateral & 1 & 0 & 1 \\
\hline \multicolumn{4}{|l|}{ Division of pain } \\
\hline V1 & 4 & - & 4 \\
\hline V2 & 25 & 13 & 38 \\
\hline V3 & 30 & 16 & 46 \\
\hline $\mathrm{V} 1,2$ & 7 & 4 & 11 \\
\hline $\mathrm{V} 1,3$ & 3 & 3 & 6 \\
\hline $\mathrm{V} 1,2,3$ & 12 & 3 & 15 \\
\hline $\mathrm{V} 2,3$ & 61 & 29 & 90 \\
\hline \multicolumn{4}{|l|}{ Previous therapy } \\
\hline Carbamazepine & 142 & 68 & 210 \\
\hline Alcohol or glycerin injection & 37 & 3 & 40 \\
\hline radiofrequency treatment & 45 & 10 & 55 \\
\hline \multicolumn{4}{|l|}{ Other diseases } \\
\hline Systemic hypertension & 43 & 13 & 56 \\
\hline diabetes & 11 & 6 & 17 \\
\hline multiple sclerosis & - & 3 & 3 \\
\hline Facial spasm & 3 & - & 3 \\
\hline glossopharyngeal neuralgia & 1 & - & 1 \\
\hline
\end{tabular}


Table II: Responsible Artery and Abnormal Findings in Operation

\begin{tabular}{|c|c|c|c|}
\hline & MVD & MVD+PSR & Total \\
\hline \multicolumn{4}{|l|}{ Responsible artery } \\
\hline SCA & 108 & 59 & 167 \\
\hline IACA & 10 & 4 & 14 \\
\hline SCA-IACA & 23 & 4 & 27 \\
\hline VA & 1 & & 1 \\
\hline BA & & 1 & 1 \\
\hline Vein compression & 35 & 11 & 46 \\
\hline Arachnoid adhesion & 12 & 7 & 19 \\
\hline
\end{tabular}

SCA; superior cerebellar artery, IACA; arteriae inferior anterior cerebelli, VA; vertebral artery, BA; arteriae basilaris.

Table III: Surgical Outcomes of MVD\&MVD+PSR

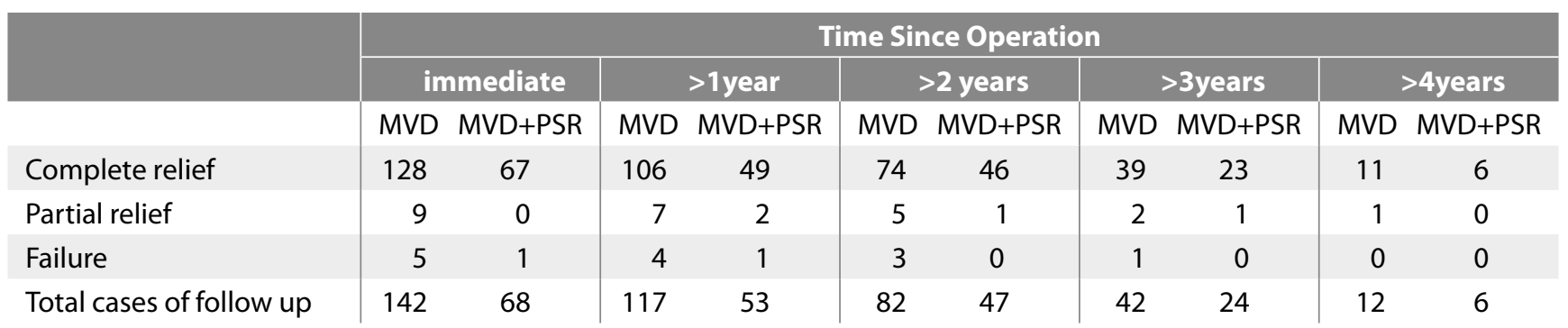

\section{DISCUSSION}

TN is characterized by "a sudden brief, usually unilateral, severe, recurrent pain in the distribution of one or more branches of the fifth cranial nerve", usually evoked by trigger factors such as washing, shaving, biting or brushing the teeth (8), and typical ache is the most important and directly evidence of diagnosis. CT or MRI was carried out to rule out symptomatic TN evoked by other diseases, such as epidermoid cyst, meningioma, trigeminal schwannomas located at cerebellopontine angle. Preoperative magnetic resonance imaging has been carried out to confirm the NVC, and there is some valuable information obtained $(1,12,20)$. Although a clearer view of anatomical relationships between the trigeminal nerve and potentially vessels has come true in high resolution magnetic resonance imaging, personally, I was still in doubt on its value of MRA as candidate selection for MVD: first, in normal anatomy, the superior cerebellar artery was very near to trigeminal nerve, which was the most seen responsible artery to $\mathrm{TN}$; second, pre-operative NVC confirmation was not clear-cut in most cases, artery or venous compression could not be ruled out even if no evidence exist in high resolution magnetic resonance imaging. Studies reporting surgical findings for recurrent TN have shown that veins or small compressing arteries are most frequently the causative agents for patients who undergo second operations (13). We have applied this technique in some patients and found the most valuable information was ascertain the probable variation of artery, such as abnormal enlargement of artery, snake like aneurysm, cerebral vascular malformations. There is an abnormal enlargement of vertebral artery in our series, which occupied almost the whole volume of CPA, any section of the trigeminal nerve could be exposed in field of vision. Another important role of preoperative imaging of CT or MRI was diagnosis of MS, which may accompanied with TN, more attention should be paid on if patients have additional neurologic signs and symptoms, especially to bilateral TN which occupied $14 \%$ of TN accompanied MS (9). In two studies of 429 and 1882 patients with MS, TN occurred in $4.9 \%$ and $1.9 \%$ respectively; approximately $2 \%$ of patients with trigeminal neuralgia have MS $(9,17)$. It was general acknowledged that MVD was not advocated for patients with TN and MS, this pain condition is caused by central demyelination and not by the neurovascular compression. In our 4 cases of MS underwent MVD+PSR, all were pain-free with a follow up more than 2 years, a fairly outcome attained than most outcomes reported in literature.

As one of effective treatment modality been used, partial sensory rhizotomy has rarely been carried out for TN patients recently, the higher incidence of dysesthesia and recurrence seriously restricts its application. MVD has been generally acknowledged with more sustained pain relief and a lower incidence of recurrence than other procedures ,Unfortunately, MVD is not always successful, there are still considerable recurrent patients after MVD, who are urgently need further treatment for the intolerable pain. In a review of 1,204 patients by Barker with a median follow-up period of 6.2 years, 70\% were reported pain-free without needing any medication (2). In our MVD group, although the degree and frequency of ache decreased obviously in almost all of patients, but tic pain and pain remnant were still in high proportion, not satisfied 
by patients. Could PSR be performed as an adjunctive therapy to secure the effectiveness for MVD? Especially to some conditions under which there was a higher recurrence of MVD. Burchiel (5) proposed a broad classification of TN, including TN1 characterized by sharp, shooting, electrical shock-like episodic pain and TN2 characterized by constant aching, throbbing, burning pain more than $50 \%$ of time, to TN2 and symptomatic TN associated with MS, there were a higher recurrent rate of MVD. In our experience, outcomes of MVD will be in doubt in these conditions, such as venous vessel compression, atypical mini-artery compression and vessel passing through the trigeminal nerve. Atypical pain and young patients had a higher recurrence rate, older patients with MS were more prone to recurred after MVD. Whereas, memorable onset and trigger points of TN were predictive of better postoperative pain relief in both atypical and typical TN.

In the 68 patients underwent MVD+PSR in our series, only 1 case was not pain free, 2 were alleviated significantly, the others were all pain free. To some extent, the data presented was able to support multi-factor theory of trigeminal neuralgia occurred, which illustrated that vascular compression was the major factor but not the only factor, because the degeneration and sclerosis in the root of the trigeminal nerve played a significant role in thological process. Therefore, some patients were advised to undergo MVD+PSR, especially in preoperative imaging findings of multiple sclerosis, with intraoperative findings of un-confirmed responsible vessel or possible vessel compression handled for poor ideal. For elderly patients increased with age, the MVD + PSR surgery should be performed if he physical conditions allowed, due to the high recurrence rate of other treatments with a loss of the final opportunity to cure the disease. Nevertheless, MVD alone was able to be advocated for young patients, combined with TN1 pain or unable to suffer from postoperative trigeminal sensory dysfunction.

Although the period of follow up was not long enough, most surpass two years, whereas in the literature most recurrences of TN after MVD occurred in the first two years after operation $(2,7,21,23,25)$, the recurrence rate decreased thereafter, and so there was conviction of our data in certain degree. Why did MVD+PSR improve the surgical outcomes? Perhaps the transmission duct was destroyed by PSR, or the trigeminal root alterations such as demyelization changed more than pure MVD, in fact, maybe the mechanism of pain relief after MVD was more complex than simply neural compression. Ganglion neuron function alternation hypothesis may give further elucidation: MVD+PSR have a greater influence on ganglion or trigeminal root than pure MVD. Ganglion neuron function alternation was supposed playing an important role in cure of TN by surgical procedures, such as PBC, RTR, PSR, and MVD (24). All the procedures mentioned above had a common feature, all causing injury to trigeminal root or ganglion, then alternating the function of ganglion neuron accordingly. Even though the effectiveness of MVD is believed just by removing compressing vascular structures, without damage to ganglion or trigeminal root directly, MVD may change the function of ganglion neuron via decompressing. Another evidence support the theory was herpes simplex virus (HSV) reactivation from latent infection of trigeminal ganglion neurons. HSV reactivation was reported in 27 to $94 \%$ of patients who underwent procedures mentioned above $(4,15,18,19,26)$, which was a common complication, occurred in 49 patients (23.3\%) in our series, 35 in MVD and 14 in MVD+ PSR group, respectively. Interestingly, we noticed one patient in our series, he was still in pain after operation, and then ache disappeared 6 days later, just at the same time when labial herpes occurred.

Veins compression as the sole responsible factor causing TN was very rare, so finding the responsible artery was the most important thing even if veins was in doubt. When veins are the offending vessels, the rates of recurrence are higher. In a review of electronic search of patient records from 1988 to 1998 , Lee (13) reported 393 TN patients caused by veins and treated with MVD, recurred in 122 patients (31\%). Venous compression my play an important role in recurrence of TN, in 32 consecutive recurrent TN attributable to veins, Lee found development of new veins around the nerve root in 28 cases (87.5), after successful subsequent MVD procedures, the pain was improved in $81.3 \%$ of the cases. Studies reporting surgical findings for recurrent TN have shown that small compressing arteries, veins compression and Teflon adhesion compression were major factors cause long-term failures. Cho (6) reported that arterial compression for $22.6 \%$, veins for $12.9 \%$, and Teflon compression for $12.9 \%$ in the second operations. In our experience, the veins adhere to trigeminal root should be coagulated and cut off, just displace by Teflon cotton was not an intelligent choice, for the veins are fragile to break and difficult to be removed, cut off can completely rule out the probable compression. In our series, 46 patients underwent veins cutting off, no complications occurred due to this procedure. Superior petrosal vein and its branches should be reserve, only when it seriously affects the vision of approaching, for in a limited operation space, coagulating of veins was relatively difficult when bleeding.

Complications after MVD were rarely seen in our series and there was no mortality or hemorrhage or infarction of cerebellum occurred, so we believe skilled manipulation and attentiveness could lower the probability of mortality to the lowest possible. Facial hypoesthesia or numbness was a major obstacle to PSR, and occurred in most or all reported patients that underwent $(11,27)$, which was intolerable in some cases. However, there was an obviously lower proportion of facial hypoesthesia or numbness in our series, with only 23 cases in the MVD+PSR group and 2 cases in the MVD group, as the sensory loss to the face was located around the corner of mouth and very limited, and even ignored by most patients if not mentioned. Perhaps only $1 / 4-1 / 5$ breadth of sensory root cutting off and without using coagulation play an important role. Surely none of them lost the corneal reflex, because the ophthalmic segment is located at the anterior of the intrinsic somatotopy of the nerve. Carefully sealing the 
mastoid air cell with bone wax could prevent cerebral spinal leakage, although in some cases the dura was not sown up closely. Interestingly, POCD occurred in 5 cases although it is rarely reported in TN patients in the literature. It presented as anxiety and restlessness, impaired orientation force and perceptivity, especially at night. All were cured by aloperidin and the symptoms vanished several days after the operation. As known, POCD usually occurs in old patients after general anesthesia (3), and the higher occurrence rate in TN patients was perhaps due to the long time anxiety and depression caused by the intolerable pain.

\section{CONCLUSIONS}

We advocate that MVD+PSR is obviously superior to MVD in completely eliminating pain in short-term period after operation. The former still has a higher pain-free rate than the latter two years after the operation, however, longer painfree rate need even longer time to follow up. Identifying the responsible vascular exactly and handling it reasonably were key to both groups. There are both merits and shortcomings in MVD or MVD+PSR, so choosing a more suitable surgical method depends on the findings in operation, and the patient's own opinion and conditions should also be considered prudently before operation.

\section{REFERENCES}

1. Adamczyk M, Bulski T, Sowińska J, Furmanek A, BekiesińskaFigatowska M: Trigeminal nerve - artery contact in people without trigeminal neuralgia-MR study. Med Sci Monit 13: 38-43, 2007

2. Barker FG II, Jannetta PJ, Bissonette DJ, Larkins MV, Jho HD: The long-term outcome of microvascular decompression for trigeminal neuralgia. N Engl J Med 334: 1077-1083, 1996

3. Bekker AY, Weeks EJ: Cognitive function after anaesthesia in the elderly. Best Pract Res Clin Anaesthesiol 17: 259-272, 2003

4. Belber CJ, Rak RA: Balloon compression rhizolysis in the surgical management of trigeminal neuralgia. Neurosurgery 20: 908-913, 1987

5. Burchiel KJ: Microvascular decompression for trigeminal neuralgia. J Neurosurg 108: 687-688, 2008

6. Cho DY, Chang CG, Wang YC, Wang FH, Shen CC, Yang DY: Repeated operation in failed microvascular decompression for trigeminal neuralgia. Neurosurgery 35:665-670, 1994

7. Broggi G, Ferroli P, Franzini A, Servello D, Dones I: Microvascular decompression for trigeminalneuralgia: Comments on a series of 250 cases, including 10 patients with multiple sclerosis. J Neurol Neurosurg Psychiatry 68:59-64, 2000

8. Headache Classification Subcommittee of the International Headache Society: The international classification of headache disorders: 2nd (ed). Cephalalgia 24: 9-160, 2004

9. Hooge JP, Redekop WK: Trigeminal neuralgia in multiple sclerosis. Neurology 45: 1294-1296, 1995

10. Kanpolat Y, Savas A, Bekar A, Berk C: Percutaneous controlled radiofrequency trigeminal rhizotomy for the treatment of idiopathic trigeminal neuralgia: 25-year experience with 1600 patients. Neurosurgery 48: 524-532, 2001
11. Klun B: Microvascular decompression and partial sensory rhizotomy in the treatment of trigeminal neuralgia: Personal experience with 220 patients. Neurosurgery 30: 49-52, 1992

12. Kress B, Schindler M, Rasche D, Hähnel S, Tronnier V, Sartor K, Stippich C: MRI volumetry for the preoperative diagnosis of trigeminal neuralgia. Eur Radiol 15: 1344-1348, 2005

13. Lee SH, Levy El, Scarrow AM, Kassam A, Jannetta PJ: Recurrent trigeminal neuralgia attributable to veins after microvascular decompression. Neurosurgery 46: 356-361, 2000

14. Lichtor T, Mullan JF: A 10-year follow-up review of percutaneous microcompression of the trigeminal ganglion. J Neurosurg 72: 49-54, 1990

15. Lunsford LD, Bennett MH: Percutaneous retrogasserian glycerol rhizotomy for tic doloureux: Part 1. Technique and results in 112 patients. Neurosurgery 14: 424-430, 1984

16. Mathews ES, Scrivani SJ: Percutaneous stereotactic radiofrequency thermal rhizotomy for the treatment of trigeminal neuralgia. Mt Sinai J Med 67: 288-299, 2000

17. Osterberg A, Boivie J, Thuomas KA: Central pain in multiple sclerosis--prevalence and clinical characteristics. Eur J Pain 9: 531-542, 2005

18. Pazin GJ, Armstrong JA, Lam MT, Tarr GC, Jannetta PJ, Ho M: Prevention of reactivated herpes simplex infection by human leukocyte interferon after operation of the trigeminal roots. $\mathrm{N}$ Engl J Med 301:225-230, 1979

19. Pazin GJ, Ho M, Jannetta PJ: Reactivation of herpes simplex virus after decompression of the trigeminal nerve root. J Infect Dis 138:405-409, 1978

20. Satoh T, Onoda K, Date I: Preoperative simulation for microvascular decompression in patients with idiopathic trigeminal neuralgia: Visualization with three-dimensional magnetic resonance cisternogram and angiogram fusion imaging. Neurosurgery 60: 104-113, 2007

21. Sindou M, Leston J, Decullier E, Chapuis F: Microvascular decompression for primary trigeminal neuralgia: Longterm effectiveness and prognostic factors in a series of 362 consecutive patients with clear-cut neurovascular conflicts who underwent pure decompression. J Neurosurg 107: 1144-1153, 2007

22. Skirving DJ, Dan NG: A 20-year review of percutaneous balloon compression of the trigeminal ganglion. J Neurosurg 94: 913-917, 2001

23. Tatli $M$, Satici $O$, Kanpolat $Y$, Sindou M: Various surgical modalities for trigeminal neuralgia: Literature study of respective long-term outcomes. Acta Neurochir (Wien) 150: 243-255, 2008

24. Tenser RB: Trigeminal neuralgia: Mechanisms of treatment. Neurology 51: 17-19, 1998

25. Tyler-Kabara EC, Kassam AB, Horowitz MH, Urgo L, Hadjipanayis C, Levy El, Chang YF: Predictors of outcome in surgically managed patients with typical and atypical trigeminal neuralgia: Comparison of results following microvascular decompression. J Neurosurg 96: 527-531, 2002

26. Young RF: Glycerol rhizolysis for treatment of trigeminal neuralgia. J Neurosurg 69: 39-45, 1988

27. Zakrzewska JM, Lopez BC, Kim SE, Coakham HB: Patient reports of satisfaction after microvascular decompression and partial sensory rhizotomy for trigeminal neuralgia. Neurosurgery 56: 1304-1311, 2005 